\title{
COMPETITION POLICY AND PRODUCTIVITY GROWTH: AN EMPIRICAL ASSESSMENT
}

\author{
Paolo Buccirossi, Lorenzo Ciari, Tomaso Duso, Giancarlo Spagnolo, and Cristiana Vitale*
}

\begin{abstract}
This paper estimates the impact of competition policy on total factor productivity growth for 22 industries in twelve OECD countries over 1995 to 2005 . We find a positive and significant effect of competition policy as measured by created indexes. We provide results based on instrumental variables estimators and heterogeneous effects to support the causal nature of the established link. The effect is particularly strong for specific aspects of competition policy related to its institutional setup and antitrust activities. It is also strengthened by good legal systems, suggesting complementarities between competition policy and the efficiency of law enforcement institutions.
\end{abstract}

\section{Introduction}

$\mathrm{T}$ HIS paper empirically assesses the effectiveness of competition policy in improving efficiency and productivity. ${ }^{1}$ While most economists, starting from Adam Smith, agree that competition works in the general interest, there is no such consensus on the ability of competition policy to be socially beneficial. Some economists, dating back to the Austrian school (for example, Von Mises, 1940), argue that any state intervention that interferes with free markets, including competition policy, will make society worse off. More recently, Crandall and Winston (2003) claim that, at least in the United States, antitrust law has been ineffective. Baker (2003), Werden (2003), and others strongly disagree. The debate remains unsettled.

Received for publication April 7, 2010. Revision accepted for publication May 16, 2012.

* Buccirossi: LEAR; Ciari: European Bank for Reconstruction and Development; Duso: Düsseldorf Institute for Competition Economics, HeinrichHeine University; Spagnolo: SITE, Tor Vergata, and CEPR, Stockholm School of Economics; Vitale: OECD.

This paper is based on a research project we undertook for the Directorate General for Economic and Financial Affairs of the European Commission, with the support of the Directorate General for Competition. We are indebted to Jonathan Baker, Simon Bishop, Pascal Courty, Robert Crandall, Adriaan Dierx, Fabienne Ilzkovitz, Bruce Lyons, Klaus Gugler, Giovanni Mastrobuoni, Jacques Mairesse, Roderick Meiklejohn, Francesco Montaruli, Elisabeth Mueller, Damien Neven, Susanne Prantl, Marc Roberts, LarsHendrik Röller, Jennifer Rontganger, Salmai Qari, Matt Weinberg, Christine Zulehner, and two anonymous referees for useful discussions and suggestions on various drafts of this paper. We are also grateful to participants at the WZB Conference "Deterrence in Competition Policy," the ACLE conference "To Enforce and Comply," the SFB conference 2009, the 3rd Lear Conference "The Economics of Competition Law," the EARIE Conference 2009, the CRESSE conference 2010, and seminar participants at DICE Düsseldorf, the DIW Berlin, EUI, University of Cologne, University of Paris $\mathrm{X}$, and University of Zurich for their comments. Gianmarco Calanchi, Bas Dessens, Claudia Pollio, and Constanze Quade provided excellent research assistance in building the database. T. D. gratefully acknowledges partial financial support from the Deutsche Forschungsgemeinschaft through SFB/TR 15.

A supplemental appendix is available online at http://www.mitpress journals.org/doi/suppl/10.1162/REST_a_00304.

${ }^{1}$ By competition policy, we mean the set of prohibitions and obligations that forms the substantive rules of competition (or antitrust) law together with the array of tools available to competition authorities for policing and punishing any violation of the same rules.
The theoretical and empirical literature has shown the existence of a positive relationship between competition and productivity. Nickell (1996), Blundell, Griffith, and van Reenen (1999), and Aghion et al. (2004, 2009), using firm-level data, show that product market competition spurs productivity. Aghion and Schankerman (2004) provide a theoretical framework to show that competition-enhancing policies may improve productivity. Based on this literature, we believe that there should be a positive link between a well-designed and well-enforced competition policy and total factor productivity (TFP) growth.

Hence, we estimate the impact of competition policy and some of its components on TFP growth using a sample of 22 industries in twelve OECD countries over the period 1995 to 2005. To measure competition policy, we identify and measure a set of its institutional and enforcement features that we consider key in deterring anticompetitive behaviors. We then aggregate these variables to form a set of summary indicators, the competition policy indicators (CPIs). We generate an aggregate CPI that summarizes all key features of a country's competition policy, as well as more disaggregated ones that refer only to the features of a competition policy relative to specific behaviors (for example, cartels, mergers) or only to its institutional or its enforcement features.

Controlling for country-industry and time fixed effects, product market regulation, trade liberalization, and other likely determinants of productivity growth, we find that the aggregate CPI has a positive and highly significant effect on TFP growth. When we use the more disaggregated CPIs, which allow us to separate the effects of the institutional and enforcement features and distinguish between merger control and antitrust, we find positive and significant coefficient estimates for all of these indicators, though institutions and antitrust appear to have the strongest and the most significant impact on productivity growth. For the aggregate CPI, we find the same result when we estimate the model by OLS, as well as in alternative IV specifications, which use political variables as instruments for the policy.

Competition policy is embedded in a wider and interconnected system of institutions and policies that might present inherent complementarities (Aghion \& Howitt, 2006). In our context, legal institutions stand out as particularly relevant since the enforcement of competition law is linked to the quality of a country's institutions in general and its judicial system in particular. Moreover, other competition-related policies might affect the way competition policy is enforced. We explore these interactions between institutions and policies and find complementarities among them. The effect of competition policy on TFP growth is stronger in countries 
where the costs of enforcing contracts are lower and the quality of the judicial system is higher, as well as in industries where no other sector-specific authorities are in charge of regulating the competitive process. These results point to sizable complementarities between competition policy and the efficiency of legal institutions. ${ }^{2}$ Moreover, they contribute to our identification strategy.

Our paper contributes to the still very limited empirical literature that evaluates the effectiveness of competition policy. Dutz and Aydin (1999) and Dutz and Vagliasindi (2000) use a cross-section of 52 countries and a small sample of transition economies, respectively, and find a positive effect of antitrust effectiveness on GDP growth. However, they use subjective measures of competition policy that are based on the perceptions of market participants, which, as a consequence, may not correctly represent the objective features of a competition policy regime. Konings, van Cayseele, and Warzynski (2001) and Kee and Hoekman (2007) look at the impact of the introduction of competition policy on industrial mark-ups, respectively, in Belgium and the Netherlands and in a large panel of industries in developed and developing countries. Neither of the two papers finds direct evidence of a positive effect of the introduction of competition policy or competition law on markups. ${ }^{3}$ However, the measure of competition policy they use does not appear to capture all the features likely to have an impact on its effectiveness.

Our work is also closely related to the literature that examines the impact of regulation and other competitionenhancing policies on productivity growth. Nicoletti and Scarpetta (2003) focus on the direct effect of privatization and liberalization on TFP growth. They show that market-oriented regulatory reforms significantly contributed to improving productivity in OECD countries during the

\footnotetext{
${ }^{2}$ The interaction between a country's legal rules and economic activities has attracted a great deal of interest following the work by La Porta et al. $(1997,1998)$. It has been shown that legal origins affect many dimensions, including bank ownership (La Porta et al., 2002), entry regulation (Djankov et al., 2002), labor market regulation (Botero et al., 2004), and government ownership of the media (Djankov, Glaeser et al., 2003). Some studies also looked at how the characteristics of the judiciary and other government institutions affect the security of property rights and contract enforcement (Djankov, La Porta et al., 2003; La Porta et al., 2008). On the basis of the results by Djankov, Glaeser et al. (2003) and La Porta et al. (2004), we expect that a lower level of formalism of the judicial procedures and greater judicial independence should improve the quality of the judicial review of the decisions made by competition authorities. Hence, we expect positive complementarities between several indicators of the quality of the judiciary system and competition policy. For a different view, see Malmendier (2009), who critically discusses the literature on the nexus between law, finance, and growth. The debate is still unsettled, and it is not the aim of this paper to enter it.

${ }^{3}$ See also Sproul (1993), who finds that prices increase in industries after a cartel has been discovered and convicted; Clarke and Evenett (2003), who find that the vitamin cartel reduces cartel prices in jurisdictions where antitrust conviction is more likely and costly; and Voigt (2009), who finds a positive effect of a set of indicators of the quality of competition policy on total factor productivity that disappears, however, when controlling for institutional quality.
}

1990s. ${ }^{4}$ Pavcnik (2002) finds a direct impact of trade liberalization on productivity improvements, which works through the reallocation of resources to more efficient producers. Several other papers look at the effect of competition and entry on productivity growth (Griffith \& Harrison, 2004; Aghion et al., 2009). They use policy variables, such as the introduction of the EU single-market program or the U.K. privatization program, as instruments for competition, which is proxied by the price-cost margin, and entry. They show that these policies have a positive impact on competition and entry, and this in turn increases productivity. Unlike these latter studies, we focus on the direct effects of competition policy on productivity growth, without attempting to identify the channels through which this happens.

The remainder of the paper is organized as follows. Section II presents and discusses our empirical model and the identification strategy. Section III presents the CPIs and the data sample. Section IV discusses our results. Section V briefly concludes. Further information about the construction of the variables, as well as several additional regressions and robustness checks are reported in the extensive online appendix.

\section{Econometric Specification}

The objective of competition policy is to deter behaviors that reduce competition. Therefore, the causal link between competition policy and efficiency goes through the impact of the former on market competition. Aghion and Schankerman (2004) provide a theoretical framework for explaining this link. They point out that competition-enhancing policies may improve productivity by facilitating the weeding out of less efficient firms; promoting cost reduction investments by incumbent firms; and encouraging entry of new, more efficient firms. 5 To make robust causal inference on the effectiveness of competition policy, we analyze the direct link between the policy and TFP growth in country $i$, industry $j$, at time $t\left(\triangle T F P_{i, j, t}\right): 6$

$$
\Delta T F P_{i, j, t}=\alpha+\beta C P I_{i, t-1}+\varepsilon_{i, j, t},
$$

${ }^{4}$ These results are partially challenged by Bourlès et al. (2010) and Amable, Demmou, and Ledezma (2009).

5 More generally, competition acts as a selection process that reallocates market shares in favor of the most productive firms. Haskel (2000) provides empirical evidence of this process. Disney, Haskel, and Heden (2003) and Syverson (2004) show that competition reduces productivity dispersion, thus suggesting that inefficient firms are forced to either catch up or exit. Competition also presses managers to reduce x-inefficiency (Hicks, 1935; Leibenstein, 1966). This point is made theoretically by Nalebuff and Stiglitz (1983), while Vickers (1995), Nickell, Nicolitsas, and Dryden (1997), Griffith (2001), and Bloom and Van Reenen (2007) provide empirical evidence of a positive relationship between competition and x-efficiency.

${ }^{6}$ While under strict neoclassical assumptions, TFP disembodies technical change or dynamic efficiency, in practice it integrates a range of other efficiency effects, including those from organizational and institutional change, changes in returns to scale, and unmeasured inputs such as research and development and other intangible investments (Inklaar, Timmers \& van Ark, 2008). Moreover, industry-level TFP also captures the effects of the reallocation of market shares across firms. 
where $C P I_{t-1}$ is one of our indicators of the quality of competition policy in country $i$ at time $t-1 . .^{7}$ Following the literature (Nicoletti and Scarpetta, 2003; Griffith, Redding, $\&$ van Reenen, 2004) we model the unobserved heterogeneity by means of an error term, which takes the form $\varepsilon_{i, j, t}=$ $\psi_{i, j}+\phi_{t}+u_{i, j, t}$. The country-industry-specific fixed-effects $\left(\psi_{i, j}\right)$ account for the time-invariant unobserved heterogeneity, and the full set of time dummies $\left(\phi_{t}\right)$ controls for common macroeconomic shocks that may affect TFP growth in all countries at the same time. ${ }^{8}$

Clearly the rates of TFP growth are affected by other country-industry characteristics. Our preferred empirical specification builds on a general endogenous growth model (Aghion \& Howitt, 2006). The basic idea is that laggard industries can catch up with the technological frontier by innovating or adopting the leading technologies. Therefore, the technological and organizational transfer from technology frontier firms influences the productivity of laggard industries so that their productivity is cointegrated with that of the leader. Under the assumption of long-run homogeneity, this process has an error correction model (ECM) representation where the industry-level TFP growth $\left(\triangle T F P_{i, j, t}\right)$ in country $i$ and time $t$ depends on the technology transfer from the country on the technological frontier $\left(T F P_{L, j, t}\right)$, and the productivity gap or distance to the technological frontier $\left(T F P_{L, j, t} / T F P_{i, j, t}\right)$ (for example, Griffith et al., 2004, p. 886). ${ }^{9}$ Moreover, following Griffith et al. (2004), we also assume that other observable industry-country-specific factors related to innovation, such as trade openness, R\&D intensity $(R \& D)$, and human capital, directly affect the rate of TFP growth. The equation that we estimate is thus

$$
\begin{aligned}
\Delta T F P_{i, j, t}= & \alpha+\beta C P I_{i, t-1}+\delta \Delta T F P_{L, j, t}-\sigma \frac{T F P_{L, j, t}}{T F P_{i, j, t}} \\
& +\gamma X_{i, j, t-1}+\chi Z_{i, t-1}+\psi_{i, j}+\phi_{t}+u_{i, j, t},
\end{aligned}
$$

where $X_{i, j, t-1}$ are country-industry-specific control variables (human capital, trade openness, R\&D, and a country-industryspecific trend), and $Z_{i, t-2}$ are country-specific controls (product market regulation and the quality of institutions).

\footnotetext{
${ }^{7}$ We assume that the CPI has a linear effect on TFP growth. However, one might question whether competition policy might have a nonlinear impact on productivity growth akin to the nonlinear effect of competition on innovation (Aghion et al., 2001; Whinston \& Segal, 2007; Acemoglu $\&$ Cao, 2010). In the online appendix, we discuss this issue and provide theoretical as well as empirical support for our linearity assumption.

8 We run a large number of alternative specifications to analyze how these assumptions on the error terms affect our results. We find that neither the choice of different individual effects nor the accounting of potential serial correlation in the residuals affects our main conclusions. An in-depth discussion of these issues can be found in the online appendix.

${ }^{9}$ Some recent papers have suggested that competition-enhancing policies may also influence TFP growth through an indirect channel, by interacting with the distance to the technological frontier (Acemoglu, Aghion, \& Zilibotti, 2006; Aghion et al., 2009; Nicoletti \& Scarpetta, 2003; Amable et al., 2009; Bourlès et al., 2010). Therefore, in the online appendix, we look at an additional specification where the effect of competition policy on TFP is interacted with the technology gap. We find a larger impact for industries further away from the technological frontier, suggesting that effective competition in laggard sectors is even more important.
}

\section{A. Identification}

The identification of a causal link between competition policy and productivity growth crucially relies on the ability to account for the potential endogeneity of our key policy variables. Especially when we look at country-level aggregates, endogeneity might arise from omitted variable bias, as well as from two-way causality and measurement errors.

We think that two-way causality is not a major concern in our case. In principle, the application of competition policy might be focused on less competitive and productive markets, which might lead to a negative correlation between the CPIs and the error term. However, our CPIs aggregate several institutional characteristics, which are unlikely to respond swiftly to changes in TFP growth rates. Institutions slowly evolve over time and quite independently of specific and short-run changes in market outcomes. ${ }^{10}$ Even the elements of the CPIs that capture some relevant enforcement features, such as human and financial resources, depend on political decisions that generally take time to be put into practice. In any case, in order to reduce the potential bias resulting from twoway causality, we use lagged values of the policy variables with respect to our dependent variable. This is a standard approach that relies on the assumption that the lagged values of the policy are uncorrelated with the error terms of the estimated equation (Griffith et al., 2004, for example, use this exclusion restriction to identify the causal effect of $R \& D$ on industry TFP growth).

The main identification issue in the context of our model is related to the existence of an omitted variable bias. The panel structure of our data set allows us to control for time-invariant unobserved individual heterogeneity at the industry-country level through fixed effects, as well as for time fixed effects. However, there might still be time-varying unobserved heterogeneity. In particular, this might derive from the existence of several other competition-enhancing policies or, more generally, other policies correlated with competition policy that might affect TFP growth rates. In our basic specifications, we control for those that we believe are the most prominent policies affecting competition-product market regulation, liberalization, and privatization - and for trade openness. We are confident that these controls should help mitigate the endogeneity problem. Nonetheless, we propose a twofold approach to provide further evidence on the causal nature of the link between competition policy and productivity growth.

First, we propose an IV approach, which allows us to explicitly test whether endogeneity matters and control for another source of potential inconsistency of the OLS estimates: the existence of measurement errors. Following some

\footnotetext{
${ }^{10}$ For instance, the introduction of leniency programs, or the adoption of the EU competition law model in eastern European countries, is more likely to be the consequence of the diffusion of some institutional innovations rather than a response to inadequate short-run market performances.
} 
recent contributions, which find political variables to determine policy outcomes (Besley \& Case, 2000; Duso \& Röller, 2003; Duso \& Seldeslachts, 2010), we use the government's ideological positions on regulatory issues as possible instruments. ${ }^{11}$

Second, in addition to the IV estimation, we adopt a less formal approach to improve our identification strategy, which looks at potential heterogeneous effects of competition policy on TFP growth. We search for situations where we expect competition policy to have a differential effect on productivity as compared to other omitted factors or policies. If we were to observe this kind of behavior in the data, this would enhance our confidence that the estimated nexus between the quality of a competition policy regime and TFP growth can be interpreted in a causal way.

We think two dimensions of heterogeneity are important in this respect. The first is related to country-specific characteristics. We expect competition policy to be more effective in countries where the quality of the legal institutions is higher. In fact, national courts are strongly involved in the enforcement of competition policy, as they often retain the power to adjudicate antitrust cases either directly or in appeal. Yet, crucial for our argument, courts are not directly involved in the adoption of other productivity-enhancing policies (for instance, regulation, $\mathrm{R} \& \mathrm{D}$ subsidies or fiscal policy). The second dimension of heterogeneity we look at is related to industry-specific characteristics. Our data encompass industries belonging to both manufacturing and service sectors. We expect the former to be significantly more affected by competition policy. The reason is that services are in general subject to strong sector-specific product market regulations, such as price control, entry regulation, and state ownership, which play a more significant role in these industries than competition policy in shaping the competitive environment and, hence, productivity outcomes. This intuition is empirically supported by Nicoletti and Scarpetta (2003), who find that deregulation plays a significantly greater role in fostering productivity in services than in manufacturing sectors. This kind of regulation clashes with competition policy, and for this reason, we expect that competition policy will be less effective in industries where the tightness of product market regulation is greater. ${ }^{12}$

\footnotetext{
11 These variables are reelaborated from the data collected by Woldendorp, Keman, and Budge (2000), Cusack and Fuchs (2002), and Klingemann et al. (2006). They represent the weighted average of the government parties' programmatic positions on particular economic issues, where the weights are the number of each party's votes. As a robustness check, we also use an alternative set of instruments derived from a well-established practice in industrial organization (Hausman, 1997). This consists of using different aggregations of the potentially endogenous variables in other markets as an instrument for the same variables in the market of interest. These additional results are discussed in depth in the online appendix

${ }^{12}$ Clearly other forms of regulation, such as health and safety regulations, might also have an additional effect on productivity growth in manufacturing industries. However, these regulations are inherently different from policies that directly control the competitive process and should not affect our identification argument.
}

\section{Data Sample and Descriptive Statistics}

We estimate our model (2) on a sample of 22 industries in twelve countries over the period 1995 to 2005: Canada, the Czech Republic, France, Germany, Hungary, Italy, Japan, the Netherlands, Spain, Sweden, the United Kingdom, and the United States. ${ }^{13}$ We use data at both the national level and the industry level. National-level data are used to measure the policy variables (competition policy, product market regulation) and the quality of the institutions. The remaining variables are measured at the industry level. ${ }^{14}$

In the following sections, we briefly describe our main explanatory variables, the CPI, as well as our dependent variable TFP growth. ${ }^{15}$ Moreover, all of these variables are discussed in depth in the online appendix, where we also describe the other independent variables, as well as the instruments used in our regression. Table 1 reports the preliminary statistics and gives a very short description for all variables.

\section{A. Measuring the Quality of Competition Policy: The CPIs}

The quality of a competition policy regime should be evaluated on the basis of its ability to deter firms that operate within its jurisdiction from undertaking those behaviors that, by impairing competition, reduce social welfare. Following Becker's (1968) theory of optimal deterrence, we consider that the level of deterrence of a competition policy is determined by three fundamental elements: the size of the sanctions, the probability of detection and conviction, and the probability of errors. Several institutional and enforcement features of a competition policy regime might affect these three factors (Buccirossi et al., 2009). The features that we believe have the strongest impact on them and, hence, on the level of deterrence of anticompetitive behaviors, are the degree of independence of the competition authority with respect to political or economic interests; the separation between the adjudicator and the prosecutor in a competition case; how close the rules that make the partition between legal and illegal conducts are to their effect on social welfare; the scope of the investigative powers the competition authority holds; the level of the overall loss that can be imposed on firms and their employees if these are convicted; the toughness of a competition authority, which is given by its level

\footnotetext{
13 These countries have been selected to be representative of different legal systems (common law and civil law), to include both EU and non-EU countries and, among the EU countries, both founding members and countries that have recently entered the EU-Hungary and the Czech Republic.

14 The 22 industries (ISIC rev. 3 codes) included in the study are the following: agriculture, forestry, and fishing; mining and quarrying; food products; textile, clothing, and leather; wood products; paper, printing, and publishing; petroleum and coal products; chemical products; rubber and plastics; nonmetallic mineral products; metal products; machinery; electrical and optical equipment; transport equipment; furniture and miscellaneous manufacturing; electricity, gas, and water; construction; hotels and restaurants; transport and storage; communication; financial intermediation; and business services.

15 A more exhaustive discussion of all the issues touched on in this section can be found in the companion paper (Buccirossi et al., 2011). Moreover, the online appendix provides a more in-depth overview of the properties of some of our indicators and their distributions.
} 
TABLE 1.-PRELIMINARY STATISTICS

\begin{tabular}{|c|c|c|c|c|c|c|}
\hline & Observations & Mean & SD & Minimum & Maximum & Description \\
\hline TFP growth & 1847 & 0.0096 & 0.0686 & -0.2818 & 0.2727 & TFP growth from the EU-KLEMS database \\
\hline TFP leader & 1847 & 0.0154 & 0.0931 & -0.7863 & 0.6246 & $\begin{array}{l}\text { Country-industry with the highest TFP relative to a } \\
\text { common reference point }\end{array}$ \\
\hline Technology gap (TFP) & 1847 & 0.6891 & 0.6697 & 0 & 5.6063 & $T F P_{L j t}-T F P_{i j t}$ \\
\hline LP growth & 1863 & 0.0299 & 0.0727 & -0.2766 & 0.2796 & Growth of value added per worker \\
\hline LP leader & 1863 & 0.0459 & 0.0940 & -0.4899 & 1.2823 & $\begin{array}{l}\text { Country-industry with the highest LP relative to a } \\
\text { common reference point }\end{array}$ \\
\hline Technology gap (LP) & 1863 & 2.9848 & 5.0550 & 0 & 88.0470 & $L P_{L j t}-L P_{i j t}$ \\
\hline $\mathrm{R} \& \mathrm{D}$ & 1463 & 0.0253 & 0.0574 & 0 & 0.4041 & $\begin{array}{l}\text { Yearly industry-level R\&D expenditures over industry } \\
\text { value added }\end{array}$ \\
\hline Human capital & 1783 & 0.1171 & 0.0977 & 0.0058 & 0.5588 & $\begin{array}{l}\text { Share of high-skilled labor employed in each } \\
\text { country-industry in a given year }\end{array}$ \\
\hline Trade openness & 1847 & 1.0096 & 1.8350 & 0 & 17.2785 & Yearly industry imports over industry value added \\
\hline PMR & 1847 & 1.6721 & 0.5227 & 0.9234 & 3.0336 & OECD indicator of product market regulation \\
\hline CPI & 1847 & 0.4976 & 0.1019 & 0.3167 & 0.7035 & $\begin{array}{l}\text { Aggregate competition policy index based on subjective } \\
\text { weights }\end{array}$ \\
\hline CPI (equal weights) & 1847 & 0.4327 & 0.1028 & 0.2240 & 0.6773 & $\begin{array}{l}\text { Aggregate competition policy index based on equal } \\
\text { weights }\end{array}$ \\
\hline CPI_institution & 1847 & 0.6048 & 0.1114 & 0.3513 & 0.7735 & $\begin{array}{l}\text { Institution competition policy index based on subjective } \\
\text { weights }\end{array}$ \\
\hline CPI_enforcement & 1847 & 0.2802 & 0.1587 & 0.0499 & 0.7513 & $\begin{array}{l}\text { Enforcement competition policy index based on } \\
\text { subjective weights }\end{array}$ \\
\hline CPI_antitrust & 1847 & 0.5023 & 0.1032 & 0.3292 & 0.7047 & $\begin{array}{l}\text { Antitrust competition policy index based on subjective } \\
\text { weights }\end{array}$ \\
\hline CPI_mergers & 1847 & 0.4834 & 0.1137 & 0.1372 & 0.6999 & $\begin{array}{l}\text { Mergers competition policy index based on subjective } \\
\text { weights }\end{array}$ \\
\hline Enforcement costs & 1847 & 22.1471 & 8.2423 & 9.4000 & 33.5000 & $\begin{array}{l}\text { Cost of enforcing contracts-World Bank Doing Business } \\
\text { Database }\end{array}$ \\
\hline Rule of law & 1847 & 1.4263 & 0.4141 & 0.5251 & 1.8801 & $\begin{array}{l}\text { World Bank Worldwide Governance Indicator for rule of } \\
\text { law }\end{array}$ \\
\hline Legal system & 1847 & 8.1494 & 1.0655 & 5.5667 & 9.6246 & Index_2 (legal system) from the Fraser Institute Database \\
\hline Market regulation (per403) & 1847 & 1.3767 & 1.2564 & 0 & 5.5007 & $\begin{array}{l}\text { Government's programmatic position: need for } \\
\text { regulations }\end{array}$ \\
\hline Economic planning (per404) & 1847 & 0.3348 & 0.6229 & 0 & 2.6971 & $\begin{array}{l}\text { Government's programmatic position: need for economic } \\
\text { planning }\end{array}$ \\
\hline Welfare state limitation (per505) & 1847 & 0.5264 & 0.5679 & 0 & 1.9637 & $\begin{array}{l}\text { Government's programmatic position: need of welfare } \\
\text { state limitations }\end{array}$ \\
\hline
\end{tabular}

We present preliminary statistics for all used variables in the selected estimation sample.

of activity and the size of the sanctions that are imposed on firms and their employees in the event of a conviction; and the amount and the quality of the financial and human resources a competition authority can rely on when performing its tasks.

We collected information on each of these features. ${ }^{16} \mathrm{We}$ gathered these data separately for the three possible infringements of the antitrust legislation-hard-core cartels, other anticompetitive agreements, and abuses of dominance-and for the merger control policy in each country and for each of the years in the sample. Most of this information was directly obtained from the competition authorities of the thirteen jurisdictions included in our sample through a tailored

\footnotetext{
${ }^{16}$ For instance, to measure the quality of the law, we collected information on the standard of proof that is required when deciding on a specific type of violation, as well as the nature of the goals that inform the decision-making process. To measure the competition authority's powers during investigations, we collected information on the power to impose, or request, interim measures; the powers to gather information by inspecting the premises of the firms under investigation or the private premises of the firms' employees; and the powers to gather information by wiretapping the conversations of the firms' employees. Buccirossi et al. (2011) describe all these issues in depth.
}

questionnaire. ${ }^{17}$ These data were integrated with information derived from the OECD and from the competition authorities' own websites and publications.

The CPIs have a pyramidal structure. ${ }^{18}$ We collected data for each of the seven key features of competition policy mentioned above. Each piece of information was then assigned a score, on a scale of 0 to 1 , against a benchmark of generally agreed best practice (from worst to best). ${ }^{19}$ All the information on a specific policy feature was summarized in a separate

${ }^{17}$ Our sample includes twelve countries and thirteen jurisdictions, as it includes the European Union. We surveyed only the competition authorities that are either independent public bodies or ministerial agencies or departments; we did not survey the courts (but we have collected data on their powers and activities).

18 Our methodology is akin to the one developed by the OECD for the indicators of product market regulations (PMR) and the competition law and policy indexes (CPI). See Boylaud, Nicoletti, and Scarpetta (2000) and Conway and Nicoletti $(2005,2006)$ for the former and Høj (2007) for the latter.

${ }^{19}$ When a data entry is quantitative, it is normalized by dividing it by the highest corresponding value held by any competition authority in the sample, so even quantitative information assumes a value between 0 and 1 .The best practice is determined by relying on scientific papers and books, documents prepared by international organizations (such as the International Competition Network and the OECD), and our judgment. 
low-level index using a set of weights to linearly aggregate it. We calculated separate indexes for specific aspects of the competition policy regime (the three possible competition law infringements and mergers) to take into account the differences in the legal framework and, where possible, in the enforcement.

The low-level indicators were subsequently aggregated into two sets of medium-level indexes: one that summarizes the institutional features of the competition policy regime and one that summarizes its enforcement features. The mediumlevel indexes were then aggregated to form a number of different summary indexes. More specifically, we calculated (for each country and each year in the sample): (a) one index that refers to all antitrust infringements (the antitrust CPI) and one that refers to the merger control process (the mergers CPI); (b) one index that assesses the institutional features (the institutional CPI) and one that assesses the enforcement features (the enforcement CPI); and (c) a single index that incorporates all the information on the competition policy regime in a jurisdiction (the aggregate $\mathrm{CPI}$ ).

The weights employed in this aggregation process are based on the relevance that in our view each item deserves. ${ }^{20}$ However, to check whether our choice of weights has a decisive influence on the results, we also used three alternative weighting schemes. The first uses an agnostic approach and weights each piece of information equally. The second aggregates the features of competition policy using factor analysis. ${ }^{21}$ The correlations between the aggregate CPIs built with our weights and these two alternative CPIs are very high (0.97 and 0.96 , respectively) and significantly different from 0 at the $1 \%$ level. Third, we also used a weighting scheme based on random weights. From a uniform distribution $(0,1)$, we randomly generate 1,000 sets of weights, which are then normalized to sum to 1 . For each of these sets, we build one aggregate CPI. 22

\section{B. Dependent Variable}

In this section we describe in brief our main dependent variable: TFP growth. An in-depth description of the productivity-related measures is provided in the online appendix.

The measure of TFP growth comes from the EU-KLEMS database. ${ }^{23}$ TFP growth is measured by the Solow resid-

\footnotetext{
${ }^{20}$ We have been very conservative in the choice of the weights and departed from equal weights only for situations for which there were robust theoretical reasons to do so. Moreover, we tried to be as transparent and explicit as possible in explaining why we chose each particular weight. The in-depth description of these issues is in Buccirossi et al. (2011).

${ }^{21} \mathrm{~A}$ complete description of this alternative methodology and the results is found in Buccirossi et al. (2011).

22 In the online appendix, we report the distribution of the OLS and IV coefficients estimates for the regressions where we use these 1,000 aggregate CPIs, and we show that our main findings are not affected by the choice of the weights.

23 The EU-KLEMS project is funded by the European Commission, Research Directorate General as part of the 6th Framework Programme, Priority 8, Policy Support and Anticipating Scientific and Technological
}

ual within the growth accounting framework under certain restrictive assumptions. One of these assumptions is that prices are equal to marginal costs. Following Griffith, Harrison, and Macartney (2006), we relax this assumption by multiplying the labor and capital shares by the industry-level markup, which is estimated as the ratio between industrylevel value added and labor and capital costs (see Paquet \& Roubidoux, 2001). ${ }^{24}$ In our sample, the average TFP growth at the industry level ranges between $-1.7 \%$ for the business services sector and $3.7 \%$ for the communications sector. The average TFP growth in the entire sample is $0.0096 \%$.

We then use TFP levels to determine the technology frontier at the country-industry level and the technology gap between each country-industry and the frontier. Following the existing literature (Griffith et al., 2004; Nicoletti \& Scarpetta, 2003), we obtain the technology gap using a two-step procedure. First, we calculate the ratio between the level of TFP in each country-industry and the geometric mean of the TFP levels in all the countries included in the sample for that industry. The frontier is defined as the country-industry with the highest ratio. Second, we obtain the technology gap by subtracting all the observed country-industry ratios from the frontier ratio.

While TFP growth is a rich measure, which incorporates the effects of all inputs on production, it might be affected by measurement errors due to its complexity. Therefore, we check our results using a simpler but partial measure of efficiency: labor productivity (LP) growth. When we use LP growth as a dependent variable in our regressions, we redefine the frontier variables (the LP of the leader and the technology gap) accordingly.

\section{Simple Correlations}

Before moving to our estimation results, we look at the simple correlation between TFP growth and the CPI at the country-aggregate level. We compute a weighted average for TFP growth using the industry value added as a weight. The correlation coefficient is large and positive (0.29) and significantly different from 0 at the $1 \%$ level. We calculate a positive correlation between the average TFP growth and the CPI for most of the countries. In particular, we calculate a positive and significant correlation coefficient for the Czech Republic (0.83), France (0.32), Germany (0.43), Hungary (0.13), Japan (0.21), the Netherlands (0.39), and the United Kingdom (0.51).

Furthermore, there is a substantial variation in TFP growth measures among the 22 industries within a country. In this study we exploit this heterogeneity dimension to support our

Needs. For a short overview of the methodology and results of the EU KLEMS database, see Timmer, O’Mahaney, and van Ark (2007).

${ }^{24}$ The concerns that one might express on the ability of the markup to measure the intensity of competition in a market are not necessarily relevant for the correction implemented in the calculation of the Solow residual. Indeed, this correction cleans the TFP measure of the error due to the existence of a divergence between price and marginal cost (the markup). 
TABLE 2.-BASIC OLS REgRESSIONS: AgGREGATED INDEX

\begin{tabular}{|c|c|c|c|c|c|c|}
\hline Dependent Variable & $\begin{array}{c}\triangle T F P \\
(1)\end{array}$ & $\begin{array}{c}\Delta T F P \\
(2)\end{array}$ & $\begin{array}{c}\Delta L P \\
(3)\end{array}$ & $\begin{array}{c}\triangle T F P \\
(4)\end{array}$ & $\begin{array}{c}\triangle T F P \\
(5)\end{array}$ & $\begin{array}{c}\Delta L P \\
(6)\end{array}$ \\
\hline L.CPI & $\begin{array}{c}0.0731^{* *} \\
(0.0246)\end{array}$ & & $\begin{array}{c}0.0652^{* *} \\
(0.0219)\end{array}$ & $\begin{array}{l}0.0924^{* * *} \\
(0.0243)\end{array}$ & & $\begin{array}{l}0.0884^{* * *} \\
(0.0225)\end{array}$ \\
\hline L.CPI (equal weights) & & $\begin{array}{l}0.0848^{* * *} \\
(0.0253)\end{array}$ & & & $\begin{array}{l}0.0925^{\text {*** }} \\
(0.0209)\end{array}$ & \\
\hline TFP/LP leader & & & & $\begin{array}{c}0.0653^{* *} \\
(0.0233)\end{array}$ & $\begin{array}{l}0.0651^{* *} \\
(0.0233)\end{array}$ & $\begin{array}{l}0.0795^{* *} \\
(0.0351)\end{array}$ \\
\hline L.Techno Gap(TFP/LP) & & & & $\begin{array}{c}0.0075^{*} \\
(0.0041)\end{array}$ & $\begin{array}{l}0.00748^{*} \\
(0.0042)\end{array}$ & $\begin{array}{l}0.0113^{* * *} \\
(0.0024)\end{array}$ \\
\hline Industry trend & & & & $\begin{array}{l}0.0445^{* * *} \\
(0.0052)\end{array}$ & $\begin{array}{l}0.0464^{* * *} \\
(0.0054)\end{array}$ & $\begin{array}{l}0.0548^{* * *} \\
(0.0064)\end{array}$ \\
\hline L.Import penetration & & & & $\begin{array}{l}0.0144^{* * *} \\
(0.0039)\end{array}$ & $\begin{array}{l}0.0144^{* * *} \\
(0.0039)\end{array}$ & $\begin{array}{r}0.0235^{* *} \\
(0.00897)\end{array}$ \\
\hline L.PMR & & & & $\begin{array}{c}-0.0312 \\
(0.0196)\end{array}$ & $\begin{array}{c}-0.0264 \\
(0.0203)\end{array}$ & $\begin{array}{c}-0.0143 \\
(0.0161)\end{array}$ \\
\hline Constant & $\begin{array}{c}-0.288^{* * *} \\
(0.0140)\end{array}$ & $\begin{array}{c}0.171^{* * *} \\
(0.0167)\end{array}$ & $\begin{array}{c}0.144^{* * *} \\
(0.0174)\end{array}$ & $\begin{array}{r}-0.137^{* *} \\
(0.0536)\end{array}$ & $\begin{array}{r}-0.151^{* *} \\
(0.0527)\end{array}$ & $\begin{array}{c}-0.969^{* * *} \\
(0.150)\end{array}$ \\
\hline Observations & 1,847 & 1,847 & 1,863 & 1,847 & 1,847 & 1,863 \\
\hline$R^{2}$ & 0.250 & 0.251 & 0.234 & 0.269 & 0.269 & 0.278 \\
\hline
\end{tabular}

among industries in the same country. In all regressions, we insert country-industry dummies and time dummies. Significant at $* 10 \%$, $* * 5 \%$, and $* * * 1 \%$.

identification strategy, as competition policy might affect various industries in different ways. Accordingly, we also look at the pairwise correlation between the CPI and TFP growth at the industry-country level. Again, this correlation is positive (0.08) and significantly different from 0 at the $1 \%$ level. Our empirical model starts from this simple correlation to identify the causal effect of the policy.

\section{The Results}

We first consider the simple, average effect of competition policy on productivity growth by using the various CPIs discussed in section IIIA and estimating models (1) and (2). In all regressions, we include year dummies and industry-country fixed effects to control for unobserved heterogeneity among industries and countries, as well as for time fixed effects. When estimating model (2), we further control for other competition-enhancing policies as measured by the OECD PMR index and trade liberalization, and we introduce a country-industry-specific deviation from the trend to account for potentially different business cycles at the country-industry level. Finally, we also control for the frontier-related measures. Most of the explanatory variables are lagged by one year to reduce possible endogeneity issues. Standard errors are clustered at the country level to allow for correlation among industries in the same country. We estimate the model by OLS. After discarding some extreme outliers, our sample consists of 1,847 country-industry-time observations. 25

\section{A. The Basic Model}

In column 1 of table 2 we report the results of the basic specification of model (1). The key result is that the coefficient

\footnotetext{
25 We dropped the observations corresponding to the first and the last percentiles of the TFP growth distribution.
}

estimate for the aggregate CPI is positive (0.0924) and statistically significant at the $1 \%$ level: competition policy is positively correlated to TFP growth. Our main result persists if we use an equal-weight aggregate CPI (column 2) instead of using the one built with our preferred weighting scheme, as well as if we use LP growth as an alternative dependent variable (column 3).26

We then move to our preferred and richer specification described in model (2), where we control for the TFP level at the technological frontier, the technology gap, and other competition-enhancing policies. Again, we estimate a positive and significant impact of competition policy on productivity growth, independent of whether we use our preferred aggregated CPI measure (column 4), the equal-weight aggregated CPI (column 5), or LP growth (column 6) as the dependent variable. These estimates also indicate the existence of a significant effect from an economic point of view. For instance, a coefficient estimate of 0.09 for the aggregate CPI implies an average elasticity of TFP growth with respect to the aggregate CPI of around 4.48 at the mean value of the variables. ${ }^{27}$ Estimates for all the other control variables conform to our expectations and to previous results reported in the literature. This gives us confidence about the quality of our preferred specification. In particular, we find that the TFP level of the leader, the technology gap, and import

\footnotetext{
${ }^{26}$ The number of observations for this specification is a bit different because we dropped the observations corresponding to the first and the last percentiles of the LP growth (instead of TFP growth) distribution.

${ }^{27}$ To give a more concrete idea of the economic meaning of this estimate, we can look at one example, such as the food products industry in the United Kingdom. In this industry, TFP growth in 2001 was $3.2 \%$, while in 2002 it was $5.2 \%$, with an increase of $62.5 \%$. In the same year, the U.K. aggregate $\mathrm{CPI}$ increased by $4.6 \%$. According to the estimated elasticity, the improvement in competition policy in the United Kingdom, as represented by the increase in the CPI, is responsible for $22.1 \%$ of the actual increase in TFP growth. Hence, without the improvement in the U.K. competition policy, TFP growth in 2002 would have been $4.53 \%(3.2 \% \times(1+(0.619-$ $0.221)$ ).
} 
TABLE 3.-OLS REGRESSIONS: DisAGGREGATED INDEXES

\begin{tabular}{|c|c|c|c|c|}
\hline & $\begin{array}{c}\text { OLS } \\
(1)\end{array}$ & $\begin{array}{l}\text { OLS } \\
(2)\end{array}$ & $\begin{array}{c}\text { OLS } \\
(3)\end{array}$ & $\begin{array}{c}\text { OLS } \\
(4)\end{array}$ \\
\hline TFP leader & $\begin{array}{l}0.0656^{* *} \\
(0.0233)\end{array}$ & $\begin{array}{l}0.0659^{* *} \\
(0.0232)\end{array}$ & $\begin{array}{l}0.0654^{* *} \\
(0.0233)\end{array}$ & $\begin{array}{c}0.0653^{* *} \\
(0.0234)\end{array}$ \\
\hline Industry trend & $\begin{array}{l}0.0428^{* * *} \\
(0.0051)\end{array}$ & $\begin{array}{l}0.0438^{* * *} \\
(0.0053)\end{array}$ & $\begin{array}{l}0.0444^{* * *} \\
(0.0051)\end{array}$ & $\begin{array}{l}0.0443^{* * *} \\
(0.0054)\end{array}$ \\
\hline L.Techno Gap & $\begin{array}{r}0.0075^{*} \\
(0.0042)\end{array}$ & $\begin{array}{c}0.0076^{*} \\
(0.0042)\end{array}$ & $\begin{array}{c}0.0075^{*} \\
(0.0041)\end{array}$ & $\begin{array}{r}0.0075^{*} \\
(0.0042)\end{array}$ \\
\hline L.Import penetration & $\begin{array}{l}0.0142^{* * *} \\
(0.0040)\end{array}$ & $\begin{array}{l}0.0144^{* * *} \\
(0.0040)\end{array}$ & $\begin{array}{l}0.0144^{* * *} \\
(0.0040)\end{array}$ & $\begin{array}{l}0.0144^{* * *} \\
(0.0040)\end{array}$ \\
\hline L.PMR & $\begin{array}{c}-0.0304 \\
(0.0196)\end{array}$ & $\begin{array}{c}-0.0266 \\
(0.0250)\end{array}$ & $\begin{array}{c}-0.0336 \\
(0.0197)\end{array}$ & $\begin{array}{c}-0.0249 \\
(0.0206)\end{array}$ \\
\hline L.CPI_institution & $\begin{array}{l}0.0705^{* * *} \\
(0.0227)\end{array}$ & & & \\
\hline L.CPI_enforcement & & $\begin{array}{r}0.0400^{*} \\
(0.0195)\end{array}$ & & \\
\hline L.CPI_antirust & & & $\begin{array}{l}0.0957^{\text {*** }} \\
(0.0255)\end{array}$ & \\
\hline L.CPI_mergers & & & & $\begin{array}{l}0.0744^{* * *} \\
(0.0221)\end{array}$ \\
\hline Constant & $\begin{array}{r}-0.133^{* *} \\
(0.0551)\end{array}$ & $\begin{array}{r}-0.117^{*} \\
(0.0594)\end{array}$ & $\begin{array}{r}-0.132^{* *} \\
(0.0526)\end{array}$ & $\begin{array}{r}-0.143^{* *} \\
(0.0587)\end{array}$ \\
\hline$R^{2}$ & 0.268 & 0.267 & 0.269 & 0.268 \\
\hline Observations & 1,847 & 1,847 & 1,847 & 1,847 \\
\hline
\end{tabular}

The dependent variable is TFP growth corrected for markups. Standard errors in parentheses are robust and allow for correlation among industries in the same country. In all regressions we insert country-industry dummies and time dummies. Significant at $* 10 \%, * * 5 \%$, and $* * * 1 \%$.

penetration have a positive and significant impact on productivity growth (whether measured as TFP or LP); while we find that product market regulation, in the form of barriers to competition, has a negative effect on productivity growth, though this is not significant as in Nicoletti and Scarpetta (2003). ${ }^{28}$ Finally, the country-industry-specific trend that we introduced to account for short-run cyclical fluctuations in demand also has a positive and significant impact. ${ }^{29}$

We then move to analyze the impact of the various dimensions of competition policy, as measured by our more disaggregated CPIs. In table 3, we focus on the difference between institutions and enforcement (columns 1 and 2) and between mergers and antitrust (columns 3 and 4). Again, we obtain results similar to those observed in our basic specifications: the various dimensions of competition policy have a positive and significant effect on productivity growth. With the exception of the antitrust CPI, the size of the effect is, however, always smaller than the one measured by the aggregate CPI, and in some cases, it is also less significant. In particular, the results for the enforcement CPI are the weakest, as the coefficient estimate drops to 0.04 and loses significance. We believe that this result is due to the quality of the information

\footnotetext{
28 In an additional specification reported in the online appendix, we look at whether the effect of competition policy on TFP growth differs depending on the size of the technology gap. The estimated effect of competition policy is much larger and more significant $(0.124)$ for country-industries further away from the frontier than for country-industries closer to the frontier (0.053).

${ }^{29}$ As we mentioned in section II, there are two other important control variables, R\&D and human capital, for which we unfortunately have many missing values. We run several additional regressions controlling for these two major drivers of productivity growth, and our results are not affected. We report and discuss these specifications in the online appendix.
}

incorporated in this index, which, because of the limited data on enforcement kept by competition authorities, covers only the level and the quality of the monetary and human resources available to competition authorities.

The established positive and significant relationship between the quality of competition policy, and in particular of its institutional design in the area of antitrust, and productivity growth, is the key finding of this study. As we discussed in section 2.1, one major concern for the causal interpretation of this effect is the potential endogeneity of the policy. A first step we have undertaken to address this issue consists of lagging the policy variables and controlling for most of the determinants of productivity growth discussed in the literature. In the next section, we provide further evidence to support our claim that the established link between competition policy and productivity growth is of a causal nature.

\section{B. Instrumental Variables}

The next step that we propose in terms of identification strategy is to use an instrumental variables (IV) approach. The results of these IV estimations are reported in table 4. Following Duso and Röller (2003) and Duso and Seldeslachts (2010), we use political variables related to the government's programmatic position toward competition and regulation as instruments for the policy. Independent of whether we instrument only for the aggregate CPI (columns 1, 3, and 5), or for both the aggregate CPI and PMR indexes (columns 2, 4, and 6), whether we use our preferred aggregate CPI (columns 1 and 2) or the equal-weight one (columns 3 and 4 ), or whether we use LP growth instead of TFP growth as dependent variable (columns 5 and 6), we always find a positive and significant coefficient estimate for the aggregate CPI. This is even larger in size than that reported in our basic OLS specifications. ${ }^{30}$ This result is reassuring, as IV estimates are consistent in the presence of endogeneity. The instruments used seem to work properly: they are correlated to the instrumented variables, as shown by the high values taken by the $F$-statistic for the excluded instruments, as well as the high value of the partial $R^{2}$ of the excluded instruments in the first-stage regressions. High values of the robust Kleibergen-Paap Wald rk F statistic signal that the instruments are not weak in the sense of Staiger and Stock (1997). Furthermore, the instruments are not correlated with the error term as shown by the Hansen $J$ statistic. In table 5, we report the first-stage regressions for the IV specifications of table 4. As expected, a pro-regulation attitude of the government (per403) and a pro-welfare limitation programmatic position (per404) are, respectively, negatively and positively correlated to the CPI (CPI_equal_weights) and positively and

\footnotetext{
${ }^{30}$ In the specifications where we use LP growth as a measure of productivity, we again have a slightly different number of observations since we drop the observations corresponding to the first and the last percentiles of the LP (instead of TFP) growth distribution.
} 


\begin{tabular}{|c|c|c|c|c|c|c|}
\hline Dependent Variable & $\begin{array}{c}\triangle T F P \\
\quad(1)\end{array}$ & $\begin{array}{c}\triangle T F P \\
\quad(2)\end{array}$ & $\begin{array}{c}\triangle T F P \\
\text { (3) }\end{array}$ & $\begin{array}{c}\triangle T F P \\
\text { (4) }\end{array}$ & $\begin{array}{c}\Delta L P \\
(5)\end{array}$ & $\begin{array}{c}\Delta L P \\
(6)\end{array}$ \\
\hline L.CPI & $\begin{array}{l}0.222^{* *} \\
(0.102)\end{array}$ & $\begin{array}{l}0.218^{* *} \\
(0.102)\end{array}$ & & & $\begin{array}{l}0.267^{* *} \\
(0.107)\end{array}$ & $\begin{array}{l}0.260^{* *} \\
(0.107)\end{array}$ \\
\hline L.CPI_equal_weights & & & $\begin{array}{c}0.134^{*} \\
(0.0694)\end{array}$ & $\begin{array}{c}0.128^{*} \\
(0.0706)\end{array}$ & & \\
\hline TFP/LP leader & $\begin{array}{l}0.0638^{* * *} \\
(0.0186)\end{array}$ & $\begin{array}{l}0.0640^{* * *} \\
(0.0186)\end{array}$ & $\begin{array}{l}0.0645^{* * *} \\
(0.0185)\end{array}$ & $\begin{array}{l}0.0647^{* * *} \\
(0.0185)\end{array}$ & $\begin{array}{l}0.0807^{* * *} \\
(0.0179)\end{array}$ & $\begin{array}{l}0.0804^{* * *} \\
(0.0179)\end{array}$ \\
\hline L.Techno Gap (TFP/LP) & $\begin{array}{l}0.007^{*} \\
(0.004)\end{array}$ & $\begin{array}{c}0.007^{*} \\
(0.004)\end{array}$ & $\begin{array}{l}0.007^{* *} \\
(0.004)\end{array}$ & $\begin{array}{l}0.007^{*} \\
(0.004)\end{array}$ & $\begin{array}{l}0.0114^{* * *} \\
(0.0013)\end{array}$ & $\begin{array}{l}0.0113^{* * *} \\
(0.0013)\end{array}$ \\
\hline Industry trend & $\begin{array}{l}0.0487^{* *} \\
(0.0237)\end{array}$ & $\begin{array}{l}0.0486^{* *} \\
(0.0237)\end{array}$ & $\begin{array}{l}0.0487^{* *} \\
(0.0237)\end{array}$ & $\begin{array}{l}0.0482^{* *} \\
(0.0237)\end{array}$ & $\begin{array}{l}0.0603^{* *} \\
(0.0249)\end{array}$ & $\begin{array}{l}0.0601^{* *} \\
(0.0249)\end{array}$ \\
\hline L.Import penetration & $\begin{array}{l}0.0146^{* * *} \\
(0.0036)\end{array}$ & $\begin{array}{l}0.0146^{* * *} \\
(0.0036)\end{array}$ & $\begin{array}{l}0.0145^{\text {*** }} \\
(0.0036)\end{array}$ & $\begin{array}{l}0.0145^{* * *} \\
(0.0036)\end{array}$ & $\begin{array}{l}0.0241^{* * *} \\
(0.0038)\end{array}$ & $\begin{array}{l}0.0240^{* * *} \\
(0.0038)\end{array}$ \\
\hline L.PMR & $\begin{array}{c}-0.0402^{* * *} \\
(0.0137)\end{array}$ & $\begin{array}{c}-0.0493^{\text {**** }} \\
(0.0195)\end{array}$ & $\begin{array}{c}-0.0272^{* *} \\
(0.0173)\end{array}$ & $\begin{array}{r}-0.0333^{*} \\
(0.0184)\end{array}$ & $\begin{array}{r}-0.0269^{*} \\
(0.0145)\end{array}$ & $\begin{array}{c}-0.0433^{* *} \\
(0.0205)\end{array}$ \\
\hline Constant & $\begin{array}{c}-0.118^{*} \\
(0.0628)\end{array}$ & $\begin{array}{c}-0.108^{*} \\
(0.0646)\end{array}$ & $\begin{array}{c}-0.0603 \\
(0.0426)\end{array}$ & $\begin{array}{r}-0.0521 \\
(0.0466)\end{array}$ & $\begin{array}{r}-0.153^{* *} \\
(0.0663)\end{array}$ & $\begin{array}{r}-0.135^{* *} \\
(0.0682)\end{array}$ \\
\hline First-stage $F$-test (CPI) & 51.00 & 55.16 & 121.64 & 116.86 & 51.53 & 55.73 \\
\hline First-stage $F$-test (PMR) & & 268.56 & & 268.56 & & 273.56 \\
\hline Kleibergen-Paap Wald $F$-statistic & 51.00 & 50.82 & 121.64 & 112.88 & 51.53 & 51.335 \\
\hline Hansen $J$ statistic & $2.616(3)$ & $2.183(2)$ & $3.712(2)$ & $3.521(2)$ & $4.450(3)$ & $3.167(2)$ \\
\hline Wu-Hausman test & 0.2105 & 0.3357 & 0.5311 & 0.7575 & 0.2995 & 0.2478 \\
\hline Observations & 1,847 & 1,847 & 1,847 & 1,847 & 1,863 & 1,863 \\
\hline
\end{tabular}

In columns 1 to 4 , the dependent variable is TFP growth corrected for mark-ups. In columns 5 and 6 , the dependent variable is LP growth. Standard errors in parentheses are robust and allow for correlation amon industries in the same country. The instruments are per108, per403, per404, and per505. In columns 1, 3, and 5, only the CPI is instrumented, while in columns 2, 4, and 6, both CPI and PMR are instrumented. The value of the $F$-statistic for the test of excluded instruments in the first-stage regressions is reported. The Hansen $J$-statistic is distributed as a $\chi^{2}$, and the degrees of freedom parameters are in parentheses. We report the $p$-value for the Wu-Hausman $F$-statistic. In all regressions we insert country-industry dummies and time dummies. Significant at $* 10 \%$, ** $* 5 \%$, and $* * * 1 \%$.

TABLE 5.-First-STAGE REgRESSIONS

\begin{tabular}{|c|c|c|c|c|c|c|c|c|}
\hline $\begin{array}{l}\text { Specification } \\
\text { Dependent Variable }\end{array}$ & $\begin{array}{c}1 \\
\text { CPI } \\
(1)\end{array}$ & $\begin{array}{l}2 \\
\text { CPI } \\
(2)\end{array}$ & CPI_equal & ${ }_{\text {CPI_equal }}^{4}$ & $\begin{array}{c}2 \& 4 \\
\text { PMR } \\
(5)\end{array}$ & $\begin{array}{c}5 \\
\text { CPI } \\
(6)\end{array}$ & $\begin{array}{c}6 \\
\text { CPI } \\
(7)\end{array}$ & $\begin{array}{c}6 \\
\text { PMR } \\
(8)\end{array}$ \\
\hline L.per108 & $\begin{array}{l}0.1292^{* * *} \\
(0.0013)\end{array}$ & $\begin{array}{l}0.0124^{* * *} \\
(0.0013)\end{array}$ & $\begin{array}{l}0.00940^{* * *} \\
(0.00111)\end{array}$ & $\begin{array}{l}0.00880^{* * *} \\
(0.00113)\end{array}$ & $\begin{array}{c}-0.0071^{* *} \\
(0.0030)\end{array}$ & $\begin{array}{l}0.012847^{* * *} \\
(0.00124)\end{array}$ & $\begin{array}{c}0.0123^{* * *} \\
(0.00126)\end{array}$ & $\begin{array}{c}-0.00733^{* *} \\
(0.00299)\end{array}$ \\
\hline L.per403 & $\begin{array}{c}-0.0083^{* * *} \\
(0.0015)\end{array}$ & $\begin{array}{c}-0.0126^{* * *} \\
(0.0014)\end{array}$ & $\begin{array}{c}-0.00988^{* * *} \\
(0.00131)\end{array}$ & $\begin{array}{c}-0.0147^{* * *} \\
(0.00123)\end{array}$ & $\begin{array}{l}0.0578^{* * *} \\
(0.0033)\end{array}$ & $\begin{array}{c}-0.00838^{* * *} \\
(0.0015)\end{array}$ & $\begin{array}{c}-0.0128^{* * *} \\
(0.00137)\end{array}$ & $\begin{array}{c}-0.05776^{* * *} \\
(0.00324)\end{array}$ \\
\hline L.per404 & $\begin{array}{l}0.0060^{* *} \\
(0.0030)\end{array}$ & $\begin{array}{c}0.0034 \\
(0.0054)\end{array}$ & $\begin{array}{l}0.00880^{* * *} \\
(0.00263)\end{array}$ & $\begin{array}{c}0.00586^{* *} \\
(0.00268)\end{array}$ & $\begin{array}{c}-0.0353^{* * *} \\
(0.0072)\end{array}$ & $\begin{array}{c}0.0062^{* * *} \\
(0.00296)\end{array}$ & $\begin{array}{c}0.0035 \\
(0.0030)\end{array}$ & $\begin{array}{c}-0.03512^{* * *} \\
(0.0071)\end{array}$ \\
\hline L.per505 & $\begin{array}{c}0.0011 \\
(0.0039)\end{array}$ & $\begin{array}{l}0.0191^{* * *} \\
(0.0031)\end{array}$ & $\begin{array}{c}-0.0139^{* * *} \\
(0.00351)\end{array}$ & $\begin{array}{l}0.00615^{* *} \\
(0.00280)\end{array}$ & $\begin{array}{l}0.2404^{* * *} \\
(0.0075)\end{array}$ & $\begin{array}{l}0.0011 \\
(0.00397)\end{array}$ & $\begin{array}{l}0.0193^{* * *} \\
(0.0031)\end{array}$ & $\begin{array}{l}0.2406^{* * *} \\
(0.0074)\end{array}$ \\
\hline Partial $R^{2}$ & 0.1148 & 0.1229 & 0.2362 & 0.2290 & 0.4056 & 0.1148 & 0.1229 & 0.4075 \\
\hline Observations & 1,847 & 1,847 & 1,847 & 1,847 & 1,847 & 1,863 & 1,863 & 1,863 \\
\hline
\end{tabular}

The dependent variable is CPI in columns 1, 2, 7, and 8 , CPI equal weights in columns 4 and 5 , and PMR in columns 3,6 , and 9 . In columns 1 and 4 , only the CPI/CPI equal weights is instrumented, while in column 2-3, 5-6, and 8-9 both the CPI/CPI equal weights and PMR are simultaneously instrumented. The partial $R^{2}$ of excluded instruments and the value of the $F$-statistic for the test of excluded instruments in the first-stage regressions are reported. In all regressions, we insert country-industry dummies and time dummies, as well as all the other exogenous variables from the main regression. Significant at $* 10 \%$, $* * 5 \%$, and $* * * 1 \%$.

negatively correlated to PMR. A pro-EU attitude (per104) correlates positively with the CPI and negatively with the PMR index, which is consistent with the tendency of the European Commission to support the development of more competitive markets. Although always consistent, IV estimates are not efficient in the absence of endogeneity. Hence, we run a Wu-Hausman test of endogeneity and cannot reject the null hypothesis that the policies are exogenous at the $1 \%$ level. Therefore, from now on, we will focus on the OLS estimates, which, in the absence of endogeneity, are more efficient. 31

These results support our claim that the established positive link between competition policy and productivity growth can

\footnotetext{
${ }^{31}$ In the online appendix, we report the IV estimates for several of the specifications discussed in the next sections. All our results are qualitatively and quantitatively unaffected.
}

be interpreted in a causal way, as they allow us to reject the hypothesis that the policies are endogenous.

\section{Heterogeneous Effects}

In the final, informal, step of our identification strategy, we exploit the possible heterogeneous effect of competition policy. The idea is that competition policy should be more effective in countries that have a better institutional environment and in sectors that are less subject to industryspecific regulations. This should not be the case for other (omitted) policies. Moreover, the analysis of such nonlinearities with respect to the institutional environment provides a novel contribution to a recently expanding literature on the complementarities between competition policy and the efficiency of (legal) institutions (Aghion \& Howitt, 2006). The 


\begin{tabular}{|c|c|c|c|c|c|c|}
\hline & $\begin{array}{l}\text { OLS } \\
(1)\end{array}$ & $\begin{array}{l}\text { OLS } \\
(2)\end{array}$ & $\begin{array}{l}\text { OLS } \\
(3)\end{array}$ & $\begin{array}{l}\text { OLS } \\
(4)\end{array}$ & $\begin{array}{l}\text { OLS } \\
(5)\end{array}$ & $\begin{array}{l}\text { OLS } \\
(6)\end{array}$ \\
\hline Enforcement cost & $\begin{array}{c}-0.0100^{* * *} \\
(0.0007)\end{array}$ & & $\begin{array}{c}-0.0063^{* *} \\
(0.0027)\end{array}$ & & & \\
\hline Rule of law & $\begin{array}{c}0.0211 \\
(0.0298)\end{array}$ & & & $\begin{array}{c}0.0471 \\
(0.0391)\end{array}$ & & \\
\hline Legal system & $\begin{array}{c}0.0115^{*} \\
(0.0059)\end{array}$ & & & & $\begin{array}{l}0.0137^{*} \\
0.0069\end{array}$ & \\
\hline L.CPI & $\begin{array}{l}0.0830^{* * *} \\
(0.0204)\end{array}$ & & & & & \\
\hline L.CPI_LOe & & $\begin{array}{l}0.0881^{* * *} \\
(0.0143)\end{array}$ & & & & \\
\hline L.CPI_LOg & & $\begin{array}{c}0.182^{* * *} \\
(0.0324)\end{array}$ & & & & \\
\hline L.CPI_LOf & & $\begin{array}{c}0.0206 \\
(0.0406)\end{array}$ & & & & \\
\hline L.CPI_LOn & & $\begin{array}{l}0.263^{* *} \\
(0.117)\end{array}$ & & & & \\
\hline L.CPI_lEC & & & $\begin{array}{c}0.240^{*} \\
(0.122)\end{array}$ & & & \\
\hline L.CPI_mEC & & & $\begin{array}{l}0.110^{* * *} \\
(0.0256)\end{array}$ & & & \\
\hline L.CPI_hEC & & & $\begin{array}{c}0.0938^{* *} \\
(0.0368)\end{array}$ & & & \\
\hline L.CPI_IRL & & & & $\begin{array}{c}0.0837^{* *} \\
(0.0310)\end{array}$ & & \\
\hline L.CPI_mRL & & & & $\begin{array}{l}0.0945^{* * *} \\
(0.0197)\end{array}$ & & \\
\hline L.CPI_hRL & & & & $\begin{array}{r}0.117^{* *} \\
(0.0532)\end{array}$ & & \\
\hline L.CPI_ILS & & & & & $\begin{array}{c}0.0553 \\
(0.0406)\end{array}$ & \\
\hline L.CPI_mLS & & & & & $\begin{array}{l}0.0722^{* * * *} \\
(0.0253)\end{array}$ & \\
\hline L.CPI_hLS & & & & & $\begin{array}{l}0.0830^{* * *} \\
(0.0255)\end{array}$ & \\
\hline L.CPI_service & & & & & & $\begin{array}{c}0.0091 \\
(0.0501)\end{array}$ \\
\hline L.CPI_manifacturing & & & & & & $\begin{array}{c}0.143^{* * *} \\
(0.0420)\end{array}$ \\
\hline L.PMR_service & & & & & & $\begin{array}{c}-0.0485^{* *} \\
(0.0189)\end{array}$ \\
\hline L.PMR_manifacturing & & & & & & $\begin{array}{r}-0.0235 \\
(0.0188)\end{array}$ \\
\hline$R^{2}$ & 0.273 & 0.270 & 0.271 & 0.270 & 0.270 & 0.272 \\
\hline Observations & 1,847 & 1,847 & 1,847 & 1,847 & 1,847 & 1,847 \\
\hline
\end{tabular}

results of the analysis of these nonlinear effects are reported in table 6.32

In the first column, we present our basic specification where we simultaneously control for several institutional dimensions. Institutions seem to have a significant direct impact on productivity growth. Yet unlike previous studies (for example, Voigt, 2009), we find that the positive and significant effect of competition policy on productivity growth is not affected by these additional controls. This reinforces the view that our indicators are able to capture the specific features of a competition policy regime, and not the general quality of a country's institutional environment.

\footnotetext{
32 Due to the lack of space, we do not report the coefficient estimates for all control variables because they are very similar to those reported in our previous regressions.
}

In column 2 we then interact the aggregate CPI with the dummies for legal origins. While the effectiveness of competition policy is significantly higher in countries with German and Nordic legal origins, it is clearly less so in countries with French legal origins, which in our sample are France, Italy, and Spain. These results seem to be in line with findings reviewed by La Porta, Lopez de Silanes, and Shleifer (2008), who report that countries with civil law are associated with a heavier-hand regulation, which has an adverse impact on markets and economic performance.

We then explore which characteristics of a legal system are important drivers of competition policy effectiveness. To exploit in the best possible way the limited variation in our institutional data and at the same time allow for nonlinear effects through a step function, we have transformed our continuous institutional variables into categorical variables based 
on their distribution. Thus, for each institutional variable, we have defined three dummies for different levels of institutional quality: low level $l$ (up to the $33 \mathrm{rd}$ percentile of the distribution), medium level $m$ (from the 33rd to the 66th percentile), and high level $h$ (from the 66th percentile). Finally, we interact these dummies with the aggregate CPI.

In column 3 we report the results for the specification where we interact the Aggregate CPI with the dummies measuring the cost of enforcing contract (EC). ${ }^{33}$ Although competition policy seems to have a positive and significant effect, independent of the levels of contract enforcement, the effect is substantially larger-indeed more than double (0.240) for countries with low enforcement costs (CPI_lEC). Hence, our results support the view that competition policy effectiveness might be stronger in countries where law enforcement is more efficient. In columns 4 and 5, we report the results of the specifications where we interact the aggregate CPI with the Fraser rule of law (RL) index and the WGI's legal system (LS) index. ${ }^{34}$ In both cases, we observe competition policy to be less effective in countries with less efficient legal institutions, such as countries with a low rule of law or a poor legal system.

The reported results point to complementarities between competition policy and some dimensions of the legal institutions. This does not mean that policies in countries with a worse legal system or higher costs of enforcing contracts must be ineffective, but rather that their (partial) ineffectiveness can be better explained by the poor functioning of the more general legal institutions. Therefore, policy changes in these countries must be adequately designed to account for the additional constraints posed by the legal system.

The second dimension of heterogeneity of the degree of competition policy's effectiveness is industry specific. As we pointed out, most of the service industries in our sampleelectricity, gas, water, communication, financial intermediation, and so on-are subject to more or less heavy-handed sector-specific regulations, and the organization of competition in these industries is partially delegated to sectoral authorities. Our claim, therefore, is that competition policy should have less of a bite in such industries, but this should not necessarily be true for other productivity-enhancing policies, such as, fiscal policy and labor regulations. We report the results of the specification where we estimate separate coefficients for the aggregate CPI, as well as for PMR in service and manufacturing sectors in column 6 of table 6 . For the aggregate CPI, we find a large (0.143) and statistically significant coefficient estimate in the manufacturing sectors, while the coefficient is much smaller and not significant in the service industries. Moreover, similar to Nicoletti and

\footnotetext{
33 Very similar results are obtained by using the general index for contract enforcement. However, in that case, we lose Italy, since there is no information on the time needed to enforce the contracts for this country.

$34 \mathrm{We}$ also try specifications where we use subcomponents of the legal system index, specifically Independence of the Judiciary and Impartiality of the Courts, and find similar results. The discussion of all these institutional variables as well as their sources can be found in the online appendix.
}

Scarpetta (2003), we find that the coefficient for PMR is negative and significant in services but not in the manufacturing industries. ${ }^{35}$ These results conform with our expectations.

All the results reported in this section point to the existence of significant and sizable heterogeneous effects of competition policy on productivity growth. The estimated differential effects should not be expected for other public policies. Hence, these further results can be seen as additional evidence that makes us more confident about the causal nature of the link we identify.

Finally, we perform several robustness checks by using different CPIs and different measures of productivity growth, as well as different sample sizes. The results for these checks, which largely confirm our main findings, are reported and extensively discussed in the online appendix.

\section{Conclusion}

The aim of competition policy is to ensure that firms refrain from undertaking behaviors that reduce social welfare by impairing competition. By deterring anticompetitive practices, competition policy should make markets work more effectively and foster efficiency. In this paper, we estimate the effect of the key institutional and enforcement features of a competition policy, summarized in a set of indicators, the CPIs, on productivity growth in 22 industries of twelve OECD countries between 1995 and 2005.

Our results indicate that a well-designed and wellimplemented competition policy has a significant impact on TFP growth. The coefficient for the aggregate CPIs is positive and statistically significant in a variety of specifications of our model. The aggregate CPI also remains highly significant when we control for several other industry-country-specific factors, frontier-related variables, as well as the quality of a country's institutions. We obtain similar results when we look at a more disaggregated picture and separately consider the effects of a competition policy's institutional and enforcement characteristics and when we differentiate between the policing of antitrust infringements and the merger control discipline. Yet the institutional and the antitrust elements of the competition policy appear to have the strongest impact on TFP growth.

We are aware of possible identification issues and therefore adopt a multistep approach to tackle them, which is based on lagged dependent variables, instrumental variable regressions, and the exploitation of heterogeneous effects. Through this approach, we provide additional support to our claim that the link we have found between competition policy and TFP growth is of a causal nature. Furthermore, we observe complementarities between competition policy and the quality of legal institutions. The effect of the former is indeed larger in

\footnotetext{
35 We also tried to disaggregate this result even more and estimate industry-specific coefficients for the aggregate CPI and the PMR indicators. The aggregate CPI has a significant impact exclusively in manufacturing industries, while the PMR indicator mostly in service industries.
} 
countries where the enforcement costs are low and the legal system more efficient. Finally, our main findings prove to be robust to several checks, such as the use of various measures of productivity, different aggregation techniques for the CPIs, as well as several subsamples.

Our results provide support for the argument that competition policy creates gross benefits to the long-term performance of a country's economy. Nevertheless, these benefits should be compared with the costs of enforcing competition laws to perform a complete welfare assessment. Unfortunately, we did not have access to sufficiently precise and encompassing cost estimates to allow us to undertake such an analysis, which could, however, be undertaken in future work subject to further data collection. There is also scope for further refinements. Currently, we have used data on 22 industries in twelve OECD countries over ten years, but it would be interesting to expand the database so as to include more countries over a longer period and, particularly, to analyze the impact of the policy in less developed economies further away from the technological frontier. Moreover, the CPIs could be improved by including more detailed information on the enforcement features of all competition authorities and, in particular, the sanctions that are effectively imposed on convicted firms and individuals and on the number of cases investigated. However, such refinements of the CPIs are difficult to achieve because of the lack of data. Indeed, if competition authorities were to increase their accountability by collecting and keeping reliable data on the enforcement of competition policy in an easily accessible format, studying the effectiveness of competition policy would become much easier.

\section{REFERENCES}

Acemoglu, Daron and Dan Cao, "Innovation by Entrants and Incumbents," mimeograph (2010).

Acemoglu, Daron, Philippe Aghion, and Fabrizio Zilibotti, "Distance to Frontier, Selection, and Economic Growth," Journal of the European Economic Association 4 (2006), 37-74.

Aghion, Philippe, and Mark Schankerman, "On the Welfare Effects and Political Economy of Competition-Enhancing Policies," Economic Journal 114 (2004), 800-824.

Aghion, Philippe, and Peter Howitt, "Appropriate Growth Policy: A Unifying Framework," Econometrica 4 (2006), 269-314.

Aghion, Philippe, Christopher Harris, Peter Howitt, and John Vickers, "Competition, Imitation and Growth with Step-by-Step Innovation," Review of Economic Studies 68 (2001), 467-492.

Aghion, Philippe, Richard Blundell, Rachel Griffith, Peter Howitt, and Susanne Prantl, "Entry and Productivity Growth: Evidence from Microlevel Panel Data," Journal of the European Economic Association 2 (2004), 265-276.

"The Effects of Entry on Incumbent Innovation and Productivity," this REVIEW 91 (2009), 20-32.

Amable, Bruno, Lilas Demmou, and Ivan Ledezma, "Product Market Regulation, Innovation, and Distance to Frontier," Industrial and Corporate Change 19 (2009), 117-159.

Baker, Jonathan B., "The Case for Antitrust Enforcement," Journal of Economic Perspectives 17 (2003), 27-50.

Becker, Gary, "Crime and Punishment: An Economic Approach,” Journal of Political Economy 76 (1968), 169-217.

Besley, Timothy, and Anne Case, "Unnatural Experiments? Estimating the Incidence of Endogenous Policies," Economic Journal 110 (2000), $672-694$.
Bloom, Nick, and John Van Reenen, "Measuring and Explaining Management Practices across Firms and Countries," Quarterly Journal of Economics 122 (2007), 1351-1408.

Blundell, Richard, Rachel Griffith, and John van Reenen, "Market Share, Market Value and Innovation in a Panel of British Manufacturing Firms," Review of Economic Studies 66 (1999), 529-554.

Botero, Juan, Simeon Djankov, Rafael La Porta, Florencio Lopez de Silanes, and Andrei Shleifer, "The Regulation of Labor," Quarterly Journal of Economics 119 (2004), 1339-1382.

Bourlès, Renaud, Gilbert Cette, Jimmy Lopez, Jacques Mairesse, and Giuseppe Nicoletti, "Do Product Market Regulations in Upstream Sectors Curb Productivity Growth? Panel Data Evidence for OECD Countries," NBER working paper 16520 (2010).

Boylaud, Oliver, Giuseppe Nicoletti, and Stefano Scarpetta, "Summary Indicators of Product Market Regulation with an Extension to Employment Protection Legislation," OECD Economics Department working paper 226 (2000).

Buccirossi, Paolo, Lorenzo Ciari, Tomaso Duso, Giancarlo Spagnolo, and Cristiana Vitale, "Deterrence in Competition Law," WZB discussion paper SP II 2009-14 (2009).

"Measuring the Deterrence Effect of Competition Policy: The Competition Policy Indexes," Journal of Competition Law and Economics 7 (2011), 165-204.

Clarke, Julian L., and Simon J. Evenett, "The Deterrent Effects of National Anticartel Laws: Evidence from the International Vitamins Cartel," Antitrust Bulletin 48 (2003), 689-727.

Conway, P. V. Janod, and Giuseppe Nicoletti, "Product Market Regulation in OECD Countries: 1998 to 2003," OECD Economics Department working paper 568 (2005).

" "Product Market Regulation in the Non-Manufacturing Sectors of OECD Countries: Measurement and Highlights," OECD Economics Department working paper 530 (2006).

Crandall, Robert W., and Clifford Winston, "Does Antitrust Policy Improve Consumer Welfare? Assessing the Evidence," Journal of Economic Perspectives 17 (2003), 3-26.

Cusack, Thomas, and Susanne Fuchs, "Documentation Notes for Parties, Governments, and Legislatures Data Set," mimeograph, Wissenschaftszentrum Berlin für Sozialforschung (2002).

Disney, Richard, Jonathan Haskel, and Ylva Heden, "Restructuring and Productivity Growth in UK Manufacturing," Economic Journal 113 (2003), 666-694.

Djankov, Simeon, Edward L. Glaeser, Rafael La Porta, Florencio Lopez de Silanes, and Andrei Shleifer, "The New Comparative Economics," Journal of Comparative Economics 31 (2003), 595-619.

Djankov, Simeon, Rafael La Porta, Florencio Lopez de Silanes, and Andrei Shleifer, "The Regulation of Entry," Quarterly Journal of Economics 117 (2002), 1-37.

"Courts," Quarterly Journal of Economics 118 (2003b), 453-517.

Duso, Tomaso, and Jo Seldeslachts, "The Political Economy of Mobile Telecommunications Liberalization: Evidence from the OECD Countries," Journal of Comparative Economics 38 (2010), 199-216.

Duso, Tomaso, and Lars-Hendrik Röller, "Endogenous Deregulation: Evidence from OECD Countries," Economics Letters 81 (2003), 67-71.

Dutz, Mark, and Hayri Aydin, "Does More Intense Competition Lead to Higher Growth?" CEPR discussion paper 2249 (1999).

Dutz, Mark, and Maria Vagliasindi, "Competition Policy Implementation in Transition Economies: An Empirical Assessment," European Economic Review 44 (2000), 762-772.

Griffith, Rachel, "Product Market Competition, Efficiency and Agency Costs: An Empirical Analysis," IFS Working papers W01/12 (2001).

Griffith, Rachel, and Rupert Harrison, "The Link between Product Market Reform and Macroeconomic Performance," ECFIN Economic Papers 209, European Commission (2004).

Griffith, Rachel, and Rupert Harrison, and Gareth Macartney, "Product Market Reforms, Labour Market Institutions and Unemployment," Economic Journal 117 (2006), C142-C166.

Griffith, Rachel, Stephen Redding, and John van Reenen, "Mapping the Two Faces of R\&D: Productivity Growth in a Panel of OECD Industries," this REVIEW 86 (2004), 883-895.

Haskel, Jonathan, "What Raises Productivity? The Microeconomics of UK Productivity Growth," Queen Mary, University of London research paper (2000). 
Hausman, Jerry, "Valuation of New Goods under Perfect and Imperfect Competition" (pp. 209-237), in Thimoty Bresnahan and Robert Gordon, eds., The Economics of New Goods (Chicago: University of Chicago Press, 1997).

Hicks, John R., "Annual Survey of Economic Theory: The Theory of Monopoly," Econometrica 3 (1935), 1-20.

Høj, Jens, "Competition Law and Policy Indicators for the OECD Countries," OECD Economics Department working paper 568 (2007).

Inklaar, Robert, Marcel P. Timmer, and Bart van Ark, "Market Services Productivity," Economic Policy 23 (2008), 141-194.

Kee, Hiau Looi, and Bernard Hoekman, "Imports, Entry and Competition Law as Market Disciplines," European Economic Review 51 (2007), 831-858.

Klingemann, Hans-Dieter, Judith Bara, Ian Budge, Michael Macdonald, and Andrea Volkens, Mapping Policy Preferences II: Estimates for Parties, Electors and Governments in Central and Eastern Europe, European Union and OECD, 1990-2003 (Oxford: Oxford University Press, 2006).

Konings, Jozef, Patrick van Cayseele, and Frederic Warzynski, "The Dynamics of Industrial Mark-ups in Two Small Open Economies: Does National Competition Policy Matter?" International Journal of Industrial Organization 19 (2001), 841-859.

La Porta, Rafael, Florencio Lopez de Silanes, and Andrei Shleifer, "The Economic Consequences of Legal Origins," Journal of Economic Literature 46 (2008), 285-332.

La Porta, Rafael, Florencio Lopez de Silanes, and Andrei Shleifer, and Robert W. Vishny, "Legal Determinants of External Finance," Journal of Finance 52 (1997), 1131-1150.

"Law and Finance," Journal of Political Economy 106 (1998), $1113-1155$.

"Investor Protection and Corporate Valuation," Journal of Finance 57 (2002), 1147-1170.

La Porta, Rafael, Florencio Lopez de Silanes, Cristian Pop-Eleches, and Andrei Shleifer, "Judicial Checks and Balances," Journal of Political Economy 112 (2004), 445-470.

Leibenstein, Harvey, "Allocative Efficiency vs. "X-Efficiency," American Economic Review 56 (1966), 392-415.

Malmendier, Ulrike, "Law and Finance at the Origin," Journal of Economic Literature 47 (2009), 1076-1108.
Nalebuff, Barry J., and Joseph E. Stiglitz, "Information, Competition and Markets," American Economic Review, Papers and Proceedings 73 (1983), 278-283.

Nickell, Stephen J., "Competition and Corporate Performance," Journal of Political Economy 104 (1996), 724-746.

Nickell, Stephen J., Daphne Nicolitsas, and Neil Dryden, "What Makes Firms Perform Well?" European Economic Review 41 (1997), 783 796.

Nicoletti, Giuseppe, and Stefano Scarpetta, "Regulation, Productivity and Growth: OECD Evidence," Economic Policy 18 (2003), 9-72.

Paquet, Alain, and Benoit Roubidoux, "Issues on the Measurement of the Solow Residual and the Resting of its Exogeneity: Evidence for Canada," Journal of Monetary Economics 47 (2001), 595-612.

Pavcnik, Nina, "Trade Liberalization, Exit, and Productivity Improvements: Evidence from Chilean Plants," Review of Economic Studies 69 (2002), 245-276.

Sproul, Michael F., "Antitrust and Prices," Journal of Political Economy 101 (1993), 741-754.

Staiger, D., and J. H. Stock, "Instrumental Variables Regression with Weak Instruments," Econometrica 65 (1997), 557-586.

Syverson, Chad, "Product Substitutability and Productivity Dispersion," this REVIEW 86 (2004), 534-550.

Timmer, Marcel P., Mary O'Mahony, and Bart van Ark, "EU KLEMS Growth and Productivity Accounts: An Overview" (2007), http://www.euklems.net/data/overview_07I.pdf 2007.

Vickers, John, "Concepts of Competition," Oxford Economic Papers 47 (1995), 1-23.

Voigt, Stefan, "The Economic Effects of Competition Policy: CrossCountry Evidence Using Four New Indicators," Journal of Development Studies 45 (2009), 1225-1248.

von Mises, Ludwig, "Human Action: A Treatise of Economics" (1940), http://mises.org/Books/HumanActionScholars.pdf., Ludwig von Mises Institute.

Werden, Gregory, "The 1982 Merger Guidelines and the Ascent of the Hypothetical Monopolist Paradigm," Antitrust Law Review 71 (2003), 253-269.

Whinston, Michael D., and Ilya R. Segal, "Antitrust in Innovative Industries," American Economic Review 97 (2007), 1703-1730.

Woldendorp, Jaap, Hans Keman, and Ian Budge, Party Government in 48 Democracies (1945-1998) (Dordrecht: Kluwer, 2000). 